\title{
Effect of sludge amendment on soil organic carbon and glomalin related soil protein in reconstructed mine substrates during 9-year reclamation
}

\author{
Dan $\mathrm{Li}^{1}$, Ningning Yin ${ }^{1}$, Liping Wang ${ }^{1}$, Zhen Zhang ${ }^{2}$, Kang $\mathrm{Li}^{1}$, and $\mathrm{Na} \mathrm{Liu}^{1}$ \\ ${ }^{1}$ China University of Mining and Technology \\ ${ }^{2}$ South China Agricultural University
}

May 13, 2020

\begin{abstract}
A field experiment was performed in reconstructed mine substrates (RMS) constituted with coal gangue and fly ash, and sludge was added to the RMS in order to speed up the reclamation process. The effect of sludge addition on plant growth, microbial activity, soil aggregate stability and aggregation-associated soil characteristics in 9-year chronosequences was monitored. The results showed that the height and the total biomass of ryegrass with sludge amendment increased with the reclamation time and eventually reached 1.5 times and 4.3 times respectively higher than the control (CK1) after 9 years. The sludge amendment enhanced the content of aggregate binding agents such as SOC and glomalin and the soil aggregate stability. The SOC, LFOC and HFOC in RMS were increased by $151.35 \%, 247.41 \%$ and $132.82 \%$ over the CK1, respectively. Besides, the tested variables in RMS after 3-7 years were insignificantly different from them in the treatment without sludge amendment after 9 years. A similar trend was also observed for GRSP. Furthermore, a significant positive correlation between GRSP and SOC was investigated in RMS, as well as GRSP and soil structure-related variables. Biological stimulation of SOC and GRSP to soil accelerated the recovery of soil structure and ecosystem function. As a result, the sludge amendment can be used as an effective technique in soil restoration.
\end{abstract}

\section{Hosted file}

Manuscript.docx available at https://authorea.com/users/321634/articles/450849-effectof-sludge-amendment-on-soil-organic-carbon-and-glomalin-related-soil-protein-inreconstructed-mine-substrates-during-9-year-reclamation

\section{Hosted file}

Tables and figures.docx available at https://authorea.com/users/321634/articles/450849effect-of-sludge-amendment-on-soil-organic-carbon-and-glomalin-related-soil-protein-inreconstructed-mine-substrates-during-9-year-reclamation 